\title{
Birds of a Feather or by Note? Ideological Nationalization of Local Electoral Manifestos in Belgium
}

\author{
Nicolas VAn de VoORde, Nicolas Bouteca, Tom Schamp \& KristoF \\ STEYVERS
}

\begin{abstract}
Until now, scholars trying to unravel the phenomenon of nationalization have seldom considered the local policy layer or the ideological dimension as their main subject. This paper, however, studies the ideological nationalization of Flemish local party branches. It applies the method of content analysis of electoral manifestos to the local elections and examines the programmatic overlaps between the party headquarter and its local branches. An innovative nationalization measure is introduced and subsequently included in an explanatory regression model. The results show that ideological similarities are ubiquitous and especially prevailing among leftist parties, in majority-participating party branches and in large municipalities.
\end{abstract}

Keywords: • nationalization • electoral manifestos • ideology • content analysis

CoRRESPONDENCE AdDRESs: Nicolas Van de Voorde, Ph.D. Candidate, Ghent University, Department of Political Science, Centre for Local Politics, Universiteitstraat 8, 9000 Gent, Belgium, email: nicolas.vandevoorde@ugent.be. Nicolas Bouteca, Assistant Professor, Ghent University, Department of Political Science, Ghent Association for the Study of Parties and Representation, Universiteitstraat 8, 9000 Gent, Belgium, email: Nicolas.bouteca@ugent.be. Tom Schamp, Research Assistent, Ghent University, Department of Political Science, Ghent Association for the Study of Parties and Representation, Universiteitstraat 8, 9000 Gent, Belgium, email: tom.schamp@ugent.be. Kristof Steyvers, Associate Professor, Ghent University, Department of Political Science, Centre for Local Politics, Universiteitstraat 8, 9000 Gent, Belgium, email: kristof.steyvers@ugent.be. 


\section{Introduction}

Ever since the introduction of the modern liberal democratic nation-state scholars have debated the surplus of an independent local government (Kjellberg, 1995; Sharpe, 1970). The discussion traditionally revolved around the 'room for local choice' evoking a tension between local self-government and central agency (with differing degrees of discretion in co-governance). In contemporary local governance, the range of functional responsibilities for local government has increasingly widened and the nature of their actions galvanized in an empowering direction. Hence, traditional central-local regimes have been replaced with a default of multi-level governance implying multifaceted modes of policy entanglement of the various layers of government affecting local leeway in a differentiated manner (Denters, 2011; Michael. Goldsmith \& Page, 2010).

Capturing the colligated political dynamics of this debate, the thesis of nationalization of local politics has emerged as a discrete lynchpin. Originally coined to comprehend the deterritorialisation of national elections (Caramani, 2004), the concept has gradually been stretched to captivate the various dimensions of the alleged geographical homogenization of politics equally from a local government perspective. This hollowing out of place-bound heterogeneity has often been problematized with the local level identified as close to citizens taking tangible decisions that visibly affect their daily life. National influences are professed to erase the particularities of local politics.

Most of the subsequent research has been concerned with the nationalization of the supply and the success of parties in the early phases of local elections (Ackaert, 2006). The predominant perspective is ecological comparing differences between municipalities resulting in explorations of local party system nationalization (Ennser \& Hansen, 2013; Kjaer \& Elklit, 2010). Complementary efforts have widened the scope to include later phases in local elections or to reorient the unit of analysis to the individual level of politicians or voters (Kjaer \& Steyvers, 2014). Yet others have tried to sharpen insights in focussing on similarities in the structure and functioning of local chapters and their national headquarter or by scrutinizing uniformity in their policies. This paper is situated at the intersection of the latter two research areas.

Our central research question is to what extent does the nationalization of local elections apply in ideological terms? Particularly, the paper aims to scrutinize ideological nationalization as programmatic congruence through comparing electoral manifestos of local chapters with the model program provided by the central headquarters of their national mother party. Our quantitative approach measures local-national similarity through the amount of attention dedicated to designated policy categories in the manifestos. 
Somewhat surprisingly, manifestos have not attracted abundant scholarly attention in local politics (but see Agasoster, 2001; Ashworth, 2000), opposite to their regional or national counterparts (see the respective Regional and Comparative Manifestos Project). The large number of local units in each country (hampering straightforward generalizability) combined with the labour-intensive coding of manifestos (whenever readily available) pose evident problems to researchers interested in studying manifestos at the local level. We have aimed to describe the extent to which ideological nationalization is present as well as to account for variation within it based on a substantial sample of local party manifestos for the most recent local election of 2012 in Belgium.

The Belgian context could be designated as exemplary for nationalization. The local multiparty system can currently be characterized ranging from mixed (national candidate lists as well as their non-national counterparts compete and obtain seats) to predominantly national (non-national lists compete but do not obtain seats). Our empirical research is limited to lists partaking in local elections in the Northern region of Belgium (i.e. Flanders). Apart from the mundane limitations of data availability, this selectivity is justified by the Belgian particularity of a fully regionalized party system ('national' parties have seized to exist) and the gradual organic and functional inculcation of municipalities in their regional orbit stemming from consecutive rounds of state reform (Wayenberg, et al., 2011). In addition, the 2012 local elections have often been conceived as a most likely case of nationalization abetted by a surge of local anchorage of the Flemish-nationalist party N-VA in the slipstream of its preceding supra-local electoral seizure (Steyvers \& De Ceuninck, 2013).

In sum, taking party lists as the prime unit of analysis the paper provides a crosssectional account of one aspect in a ditto dimension of the wider dynamics of the nationalization of local politics, albeit important and often neglected. This study endeavours to be a theoretical addition to the current literature on the nationalization of local politics, for which it transcends common limitations that prohibit a contribution to underdeveloped study of parties at the local level and their nexus with the national realm (Kjaer \& Elklit, 2010). Moreover, by developing an innovative method to assess ideological nationalization and applying it in a representative context, the paper tries to empirically enrich the ongoing nationalization debate. Both contributions help us to unravel the key query formulated alternatively: do birds of a feather indeed flock together or is each local species known by its place-bound note?

This paper proceeds as follows. The first part elaborates on the postulates of nationalization and their implications for the ideology of party chapters in the context of local elections. The second part discusses the added value of the method proposed to measure ideological nationalization by studying the extent to which the relative attention dedicated to certain policy categories in local 
manifestos corresponds to that of the model program of their central organization. Subsequently, in the third part this yardstick will be applied to 89 local party manifestos expounded in the 2012 local elections in the Flemish region of Belgium resulting in a description of ideological nationalization scores in a relative index. Furthermore, the fourth part will exploratory account for variation in ideological nationalization by probing into the explanatory power of differences in terms of party type. We will try to determine if the ideological position, the genetic origin and the party age matter for ideological nationalization. Participation in the (outgoing) local governing majority and municipal size will serve as control variables to assess the robustness of the party type effect. Finally, the fifth part presents some overall conclusions and thoughts for further discussion.

\section{Pluming the literature: reviewing evidence for ideological nationalization in local elections}

Starting from the nationalization of electoral politics from a local government perspective (cf. first paragraph) the focus will be sharpened on the ideological nationalization of local elections as the programmatic congruence of local chapters with their national headquarter (cf. second paragraph). Pertinent insights for the Belgian case will be situated in the comparative findings.

\section{The nationalization of electoral politics from a local government perspective}

The basic tenet of nationalization holds that political differences are disappearing between the various geographic units of a nation (Lago \& Montero, 2014). Herein, the extent to which this increasing homogeneity appears in elections has become the predominant perspective. The bulk of this research has been concerned with convergence in the composition of the electoral offer and the distribution of electoral success over time and across space. Increasingly refined yardsticks have eventually spurned mixed empirical results. Whereas some have discerned a general trends towards nationalization, other accounts are more sceptical or emphasize its contingency (Caramani, 2004; Morgenstern \& Swindle, 2005).

This research is, however, predominantly concerned with the state-wide level and actually addresses the territorial homogeneity of national elections (with 'local' referring to the constituency level). To overcome this nationalism bias, several authors have proposed a multilevel perspective enclosing the various subnational tiers for a more comprehensive and fine-grained view (Deschouwer, 2003; Mustillo \& Mustillo, 2012). This would include taking local elections as an alternative frame of reference for which relatively scarce evidence on longitudinal and cross-sectional nationalization is available. Again, the evidence largely pertains to the convergence of the partisan supply and success. 
Its emergence over time is often conceived as an indicator of a process of party politicization. This a central element in the work of (Rokkan, 1966, p. 244) associated with societal modernization implying '[...] the breakdown of the traditional systems of local rule through the entry of nationally organized parties into municipal elections'. Although this dynamic conception expects an almost teleological take-over of local politics by national political parties, traditional non-partisan elements continue to hold local ground (Aars \& Ringkjob, 2005; Bäck, 2003; Kjaer \& Elklit, 2010). Apart from remaining differences in the territorial anchorage of national political parties, this is due to the enduring presence and success of various types of non-national candidate lists in local polities (Copus et al., 2012; Reiser, 2008). This phenomenon holds especially in the context of Central and Eastern Europe where national party politics was historically associated with the centralism and party authoritarianism of the Communist era. Until recently, the party system appeared in a permanent state of flux. Newly created national parties, however, have steadily infiltrated local government to a different extent compared to the communist period. Although independents dominate the local office in some countries, in others the latter is considerably more partisan (Swianiewicz, 2014).

The cross-sectional approach refers to the extent to which the national party political presence (the degree to which all state-wide parties are competing) and/or performance (the grade of territorial homogeneity of their electoral results and governing) at a given local election are geographically alike (Thorlakson, 2006). Most longitudinal findings emphasize the sustenance or divergence in the local party system nationalization. For instance, based on a discrete assessment of multilevel partisan resemblance, Kjær \& Elklit (2010) confirmed the positive effect of municipal size on nationalization in terms of votes and seats in the Danish context whereas similar evidence for Austria (Ennser \& Hansen, 2013) highlighted the (regional) degree of party organization as an additional explanatory variable.

Similar tendencies seem to occur in Belgium. In the long run, national parties have effectively superseded merely place-bound phenomena in local elections. Accelerated by municipal mergers in the mid-1970s national forces have gained imprint on the local soil (Ackaert, 2006). However, a general straightforward and increasing nationalization could not be discerned. The presence, success and shifts of and between parties are not homogenous for the whole country. Local results largely follow similar evolutions as those for national elections but dissimilarities continue to strongly characterize the geographical division of party votes (Wille \& Deschouwer, 2007). Very much alike, supply sided evidence shows that the local party field is infused with national candidate-lists. Nevertheless, non-national counterparts have maintained their presence and contributed to the production of mixed or predominantly national local party systems in at least $70 \%$ of all municipalities (Steyvers, Reynaert, De Ceuninck, \& Valcke, 2008). In addition, 
using post-electoral coalition success as an indicator, typical local factors tend to predominate with a keen eye on national considerations (Olislagers \& Steyvers, 2014).

Fragmented evidence also exists on other aspects of the nationalization of Belgian local politics. Probing into the rationales for municipal electoral choice stresses the limited nationalization of individual voting behaviour. More than $60 \%$ of all reasons voters mentioned as most important refer to local motives (Marien, Dassonneville, \& Hooghe, 2015). Finally, it seems that, based on the study of organizational congruence, one can conclude that the internal party structure varies strongly between local chapters of national parties (Deschouwer \& Rihoux, 2008).

Sharpening the focus on party ideology

As indicated above, in general, the existing evidence does not point to an overal nationalization of local politics. Ideology, however, is an aspect that has often been neglected in the discussion on nationalization of local politics. To which degree and under which circumstances can a pattern of territorial homogeneity in terms of ideology be discerned? Given the electoral and multilevel partisan focus of our paper, the latter is delineated as the programmatic congruence between local chapters of national political parties and their central headquarter in municipal elections.

The literature is not very informative in this regard. Empirical research on ideological nationalization of local elections is limited and often focused on voting behaviour (Hajnal \& Trounstine, 2014). Integrated comparative evidence from a partisan perspective is virtually non-existent. However, clues in collections of country cases can be found (Saiz \& Geser, 1999). Swianiewicz (1996) suggested, for example, that preferences of candidates for the Polish municipal election in 1994 did not allign with those of the national party. Of course, one has to consider the above-mentioned post-communist context and the immature party system, which made candidates sensitive to an association with a national party label. Also in Belgium, aspects of ideological congruence have been measured. In an eliteoriented approach key representatives of local branches were asked which issues they deemded important for their party in local elections (with nationalization depending on the pointing to identical issues by politicians from the same national party). Whereas Deschouwer (2003) did not find rock hard evidence for this type of ideological nationalization in earlier elections, follow-up for 2006 oppositely found indications for the nationalization of local politics (Devos et al. 2007; Buelens et al. 2008).

The literature suggests several reasons to assume that municipal party lists might indeed be nationalized. First of all, the national party and its local divisions share a common ideological background. For instance, one can assume that green 
politicians, both at the local and national level, will advocate for environmental protection (Devos et al., 2007). Second, local branches are programmatically interesting because they add to the mobilization capacities of national parties (Frendreis, Gibson, \& Vertz, 1990; Pedahzur \& Brichta, 2000). As a result, national headquarters provide substantial and practical support in election time. This assistence can be merely functional, supplying localities with templates for posters and leaflets, but could also include programmatic endeavours such as the provision of a model program. Layman local politicians might endorse spoon-fed national policy proposals as draughting an election manifesto is extremely timeconsuming. Although this process can be facilitate organizing local election campagings, it implicitly increases ideological nationalization.

The above elements support the assumption that local parties will emphasize central issues already claimed by their national. Issue ownership (Petrocik, 1996) is an important asset in times of elections as it increases the credibility of a party on certain matters. Moreover, national parties will try to avoid corrosion of their issue ownership by local party branches who formulate diverging policies, especially when the latter adopts the national party brand. Indeed, according to the franchise party model (Carty, 2004, p. 13), parties increasingly behave as stratarchically organized entities. The central headquarter is responsible for the overall party brand, whereas local brances exploit it in their electoral campaign. It is especially profitable for local candidates who are able to identify themselves with a reliable and well-known product. Although Carty acknowledges that divergent manifestos are possible within the framework of the franchise party, he states that the decision-making on the main programmatic issues is for the most part a central matter because it ensures: "[...] that the party is providing a consistent message to its supporters and the electorate".

On the other hand, several factors imply little local-national congruence. First, local government in Belgium and elsewhere has distinct tasks and compentences to deal with municipal-specific issues. Evidently, all governmental levels share similar problems, but each municipality has its own specific problems. Local branches will underline certain issues dominant in their commune, that do not necessarily match national tendencies. Second, some interpretations even conceive local politics as less ideological alltogether. In these, local self-government is seen as largely outside the political sphere and merely factual and harmonic. Concordance among actors to strive for the 'technically' best solution is the preferred mode of public decision-making. The non-political (i.e. non-partisan) conception of local politics is enhanced by the relative small scale of the local polity, which reduces the potential role of parties as aggregators of various interests and stresses the importance of personal relations (Copus et al., 2012). This leads Ackaert (2006, p. 113) to the conclusion that in Belgium local politics is first and foremost a matter for local politicians. We build on these existing Belgian studies and their predominant results for our first assumption: 
H1: There will be little ideological congruence between the local party manifesto and the national model program.

\section{Applied methodology and data}

Existing research on ideological nationalization has several important disadvantages due to its use of elite survey data (Buelens et al., 2008; Deschouwer, 1996; Devos et al., 2007). For example, it cannot be ruled out that politicians express their own opinion or of their faction instead of the whole party. In this paper, we therefore suggest a more reliable approach by analysing congruence based on party manifestos, which should avoid subjective interpretations of nationalization. Conversely, party manifestos represents the whole party and its ideology more accurately as they are the result of internal discussions and are usually approved by a body of the party (Budge, 1987; Gemenis \& Dinas, 2010).

Furthermore, our method is analogous to the internationally reknown research tradition for ideological research of parties at the national level, like the Comparative Manifesto Project (CMP) (Klingemann et al., 2006; Volkens et al., 2013). More specifically, this paper translates the CMP approach to the local level. For example, we also chose to code on salience and not position. Although identifying those positions could be beneficial (De Lange, 2007; Gemenis \& Dinas, 2010; Janda et al., 1995; Meguid, 2005; Pellikaan et al., 2003), we are convinced that those insights would only have a marginal added value for our specific research question. In theory, local branches could contradict the central headquarters but they do all share a common ideological baseline. We can, therefore, expect that policy positions will not fundamentally diverge.

Both the local election program and the national model program were coded to examine the ideological nationalization of local politics. The model manifestos are designed and approved by the national party board and serve as ideological guidelines for local brances. Coding the manifestos enables us to calculate the relative attention for a category (issue) in each party manifesto. These percentages are then used to calculate the Relative Nationalization Score (RNS) of a local election manifesto, i.e. the degree of resemblance between the election manifesto of local branches and the model program. First of all, for each of the categories the difference is calculated between the relative attention for a category in the local manifesto and the national manifesto. Afterwards, the sum of these 19 differences is calculated. By taking the sum of all relative differences, we avoid that large discrepancies between categories have a significant impact on the RNS. The average score would conceal small and large resemblances between certain categories. Next, the sum is divided by $200(\%)$, this is the maximum possible difference in relative attention between the model program and the manifesto of the local party branche. Finally, we substracted 1 from this score and took the 
absolute value to create the RNS. The latter is merely an esthetic intervention, rescaling the endresult to a score between 0 (perfect localization) and 1 (perfect nationalization).

$$
\begin{gathered}
R N S=\left[\left(\sum|p l-p n| / n\right)-1\right] \\
P l=\text { relative attention of the local manifesto } \\
p n=\text { relative attention of the national manifesto } \\
n=\text { maximum theoretical difference }
\end{gathered}
$$

The data collection was restricted to a subset of 89 Flemish local party manifestos, as manually coding election programs is an extremely labour intensive process. We opted for an approximately equal distribution between municipal size and the 7 Flemish parties. Only Flemish parties who can be conceived as national parties, with an appropriate organization and who contested local elections throughout the entire region, were selected. Data was retrieved for the extreme left party PVDA $(\mathrm{n}=8)$, the green party GROEN $(\mathrm{n}=14)$, the social democrats of the Sp.a $(\mathrm{n}=$ $13)$, the Christian democrats of the CD\&V $(n=17)$, the liberal party Open VLD ( $n$ $=11)$, the Flemish-nationalist party N-VA $(n=15)$ and the extreme right Vlaams Belang $(\mathrm{n}=11)$. The libertarian party, Lijst Dedecker, was not included although they were popular at the beginning of the 21th century and received 7 Flemish seats. After a quick electoral decline, however, the party opted to participate in a limited number of municipalities for the latest local elections and were therefore excluded. It should be noted that most cities are not unique in the sample, due to the relative small number of large cities in Flanders. Consequently, 89 cases does not equal 89 municipalities.

Throughout this paper one should always keep this selection bias in mind and reflect on its possible impact on our results. In total, 2840 pages of 89 local election programs were coded. A distinction was also made between real manifestos and mere pamphlets or leaflets, only manifestos containing at least 5 pages and 100 quasi-sentences were incorporated in the sample. On average, a manifesto existed of almost 32 pages or 566 quasi-sentences.

Because the original CMP coding scheme did not fit our local approach due to its national focus, an innovative coding scheme was designed to grasp ideological positions at the municipal level. The scheme contains 19 categories that were constructed deductively based on the local functions according to the legal regulation. The entire coding scheme, including a detailed inventory of the possible issues within each category, can be found in appendix a. The coding process did follow the general CMP guidelines (Volkens, 2002). First, we divided the entire manifesto into quasi-sentences, which is a sentence or a part of a sentence that contains a unique political message. Afterwards, these quasisentences were assigned to the correct category of the coding scheme. Each sentence was only assigned once to the most dominant theme the message is 
referring to. An inter-coder reliability test was performed between the main coder and one independent coder to calculate the Fleiss' Kappa measure, that estimates whether both coders classified the same quasi sentences into the same category. Our results exceeded the expected threshold of .7 (Fleiss' Kappa $=.71$ ). We argue that is more than sufficient to conclude that our scheme is both robust and reliable to grasp most local issues.

\section{Presentation of the results and probing into their variety}

In the following section, the degree of ideological nationalization of local party branches is described. Afterwards, we developped several hypotheses to account for the variation within the ideological congruence. To assure a clear overview, table 1 presents the overarching hypothesis (H1), as well as our six subhypotheses.

\section{Level of ideological nationalization}

Figure 1 shows the distribution of RNS scores of local party manifestos. The RNS varies between zero (0) and one (1): (0) means that a manifesto is perfectly localized and shows no ressemblances with the national template and (1) represents perfect nationalization and theoretically a perfect copy of the model program.

Figure 1: Distribution of the RNS scores ( $\mathrm{N}=89)$

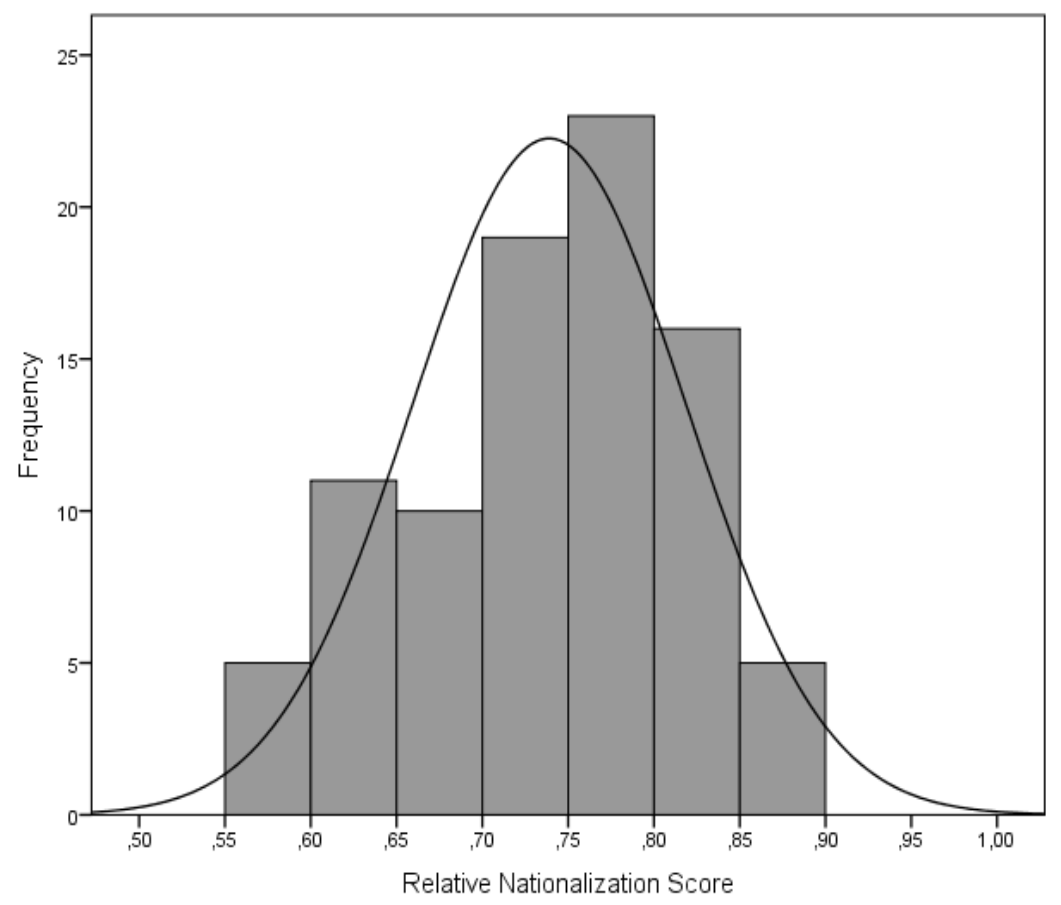


First of all, the scores between .5 and 1 are normally distributed. Most of the scores cluster around the mean result (.74) while the standard deviation is small as well (.08). The minimum score is .56, which can already be seen as a significant indication of ideological nationalization. At the other extreme end, 5 manifestoes could be categorised as very strongly nationalized as their scores range between .85 and 1. All manifestos show a high degree of similarity compared to their national model manifesto. Large deviations in terms of issue salience or relative attention for certain subjects are scarce. All local party branches seem to embrace the ideological standards of the national party, as there is limited variation in how much they rely on that template. Hence, the national model program seems to be a blueprint for the local program, which can be tinkered minimaly depending on the local needs but whose core is always to be maintained.

Hence the data suggest a very clearcut image of nationalization of the local manifestos. In short, we have found evidence to support the H1a and reject the alternative $\mathrm{H} 1 \mathrm{~b}$, i.e. confirming a widespread ideological congruence between local departments and the center.

The explanatory model: variaty assumed

We claim that the party type and the local context are detrimental to explain variation in ideological nationalization. More specifically, we hypothesize that the ideological position, the genetic origin and the party age influence the degree of congruence. Second, the municipal size and the participation in the outgoing local governing majority are local characteristics used to model the found differences.

Table 1: Overview of hypotheses

\begin{tabular}{lll}
\hline Overarching hypothesis & H1 & Little ideological nationalization \\
\hline $\begin{array}{l}\text { Explanatory hypotheses: } \\
\text { Party effect }\end{array}$ & H2a & $\begin{array}{l}\text { Rightist parties will show more ideological } \\
\text { congruence }\end{array}$ \\
& H2b & $\begin{array}{l}\text { Mass parties will show more ideological } \\
\text { congruence } \\
\text { Traditional parties will show more } \\
\text { ideological congruence }\end{array}$ \\
\hline $\begin{array}{l}\text { Explanatory hypotheses: } \\
\text { Context effect }\end{array}$ & H3a & $\begin{array}{l}\text { Local branches participating in the } \\
\text { majority will show less ideological } \\
\text { congruence } \\
\text { Local branches in large municipalities will } \\
\text { show more ideological congruence } \\
\text { Local branches in large municipalities will } \\
\text { show less ideological congruence }\end{array}$ \\
\hline
\end{tabular}




\section{Party effect}

According to some scholars (Enyedi \& Linek, 2008), rightist parties are more hierarchically organized than leftist parties. Based on their more individualistic ideology right-wing parties emphasize party leadership: party elites are in control and organized forms of member participation are more limited compared to leftwing parties. Therefore, we expect that local chapters of rightist national parties have less programmatic freedom compared to leftist local chapters. Although recent comparative research (Pilet \& Cross, 2014) does not provide rock-hard evidence of this leftist democratic tradition because all parties (left and rightwing) have made efforts to increase the voice of party members in the internal workings of the party (Heider et al., 2012; LeDuc, 2001; Wauters, 2014). We assume that the chances of ideological nationalization are larger within rightist parties.

$\mathrm{H} 2 \mathrm{a}$ : Parties of the right show a higher degree of ideological nationalization than left-wing parties.

The genetic origin of a party could also determine the extent of ideological nationalization. In this sense, parties that were originally founded as mass parties can be considered highly centralized because their national headquarters were the most important agent in the party organization. This could also entail the rather strict coordination of local party branches by the central party (Carty, 2004). Although the era of mass parties lies far behind us, Gunther and Diamond (2003, p. 174) assert that the "'founding context' can leave a lasting imprint on the basic nature of the party's organization for decades to come". As a result, we hypothesize the following:

$\mathrm{H} 2 \mathrm{~b}$ : Parties that were founded as mass parties show a higher degree of ideological nationalization than other parties.

Finally, we expect to find a difference between new parties and established parties. The younger a party is, the less organizational power it has. In contrast to established parties, new parties still have to build a viable infrastructure (Mair, 1999). Although party age is an important factor that affects the level of party organization, the era in which they were founded (from the 1960's onwards) and ideology play a role too. New parties are often 'thinner' organizations than established parties because they emerged in a context of mass communication which made it possible to communicate directly with voters instead of via the party apparatus (Gunther \& Diamond, 2003). Moreover, many new parties dissaprove strong hierarchical steering and choose for a more democratic form of organization (Bolleyer, 2011, p. 322). This less developed organization with emphasis on democratic party organization leaves more room for local autonomy.

H2c: Traditional parties show a higher degree of ideological nationalization compared to new parties. 
The operationalization of this threefolded division between parties is rather straightforward. In line with previous academic scholars, we regard the greens, the socialdemocrat and the radical left labour party (PVDA) as leftist parties. The christian democrats, liberals, regionalists and extreme right party, on the other hand, are considered rightist. This dichotomy is confirmed by both content analyses of the national party manifestos by the Manifesto Project Database and subjective self-placement scales of members (van Haute et al., 2012). Referring to the continuing impact of the founding context, only the social democrats can be classified as a true mass party. This extra-parliamentary party was set up in 1885 to represent the interest of all blue collar workers and to recruit as many as possible. Separating traditional and new parties, however, is based on their age. The Belgian party system, and both regional ones, were long dominated by three 'pillar' parties: the liberal party, the christian-democratic party and the socialist party. All three consistently shared political power at the end of the $19^{\text {th }}$ century and during the complete $20^{\text {th }}$ century. Only later on new parties began to emerge, starting with the regionalist party, the greens and the extreme rightists. None of them, however, were able to recreate the immense pillarized party structure of the three traditional parties.

\section{Context effect}

We expect that the municipal political context also shapes the extent of ideological nationalization. First, it is assumed that branches participating in local government have an information advantage over branches in the opposition. The former branches have aldermen or a mayor at their disposal, often (semi-)professional politicians, that can devote more of time to politics compared to amateur politicians. For instance, they have both the time and the knowledge to write a full-fledged and tailor-made program for their municipality. As a result, we expect parties that belonged to the majority will be less dependent on the central party for programmatic input. The data concerning municipal governing coalitions was provided by the Flemish ministery of internal affairs and enables us to distinguish governing and opposition parties before the 2012 elections. Our dataset consists of 55 parties that resided in the local coalition $(61.8 \%)$, whereas 34 local branches $(38.2 \%)$ did not belong to the majority or occupy any seats in the local council at all.

H3a: local party branches that participated in the outgoing local governing majority are less ideologically nationalized than parties who were in opposition. Second, scholars often assume that municipal size matters to understand nationalization. E.g. Ennser and Hansen (2013) and Kjaer and Elklit (2010) found that the nationalization of the party system is positively related to the size of a municipality, implying that the resemblance between the national and the local party system is larger in cities compared to small municipalities. Since both studies focus on another dimension of nationalization we cannot automatically conclude that the ideological nationalization will probably be more outspoken in 
larger cities. Nevertheless, the theoretical framework of the franchise party (2004, p. 11) offers some clues that point in a similar direction. According to this model, parties are very concerned with providing a consistent ideological message to its supporters and the electorate. In this way, cities can be considered as strategically more important for the party brand and the consistency of the party message because they get a lot more media-attention. Consequently, the headquarters will aim to influence the electoral manifestos of the large city-branches more heavily. Evidence from Poland seems to support these findings as the ideological 'color' between the local and national level was more easily deducible in larger cities (Swianiewicz, 1996). On the other hand, Carty (2004, p. 11) states that within a franchise party the relationship between the central party and the local branches can vary significantly. Larger or more important local departments may have more independence than smaller or less vital local branches. The absolute number of inhabitants per municipality was used as a proxy for the municipality size to test these hypotheses. Two contradicting hypotheses were forumulated based on the mixed theoretical guidelines.

H3b: Local party branches in large municipalities will show more ideological nationalization.

H3c: Local party branches in large municipalities will show less ideological nationalization.

\section{Presentation of the regression model: variety explained}

Before introducing the multivariate model we look at the relevant bivariate analyses of our independent variables and the RNS. Starting off with the difference between parties, figure 2 is a zoomed in distribution plot of the nationalization scores between 0.6 and 0.8 . This allows us to compare all seven parties to each other and to the entire sample as such. Contrary to our expectations, none of our proposed party types shows a clear positive or negative relation to the nationalization degee. Rightwing parties, for one, are somewhat evenly distributed between scores that demonstrate high (N-VA), medium (CD\&V and VLD) and lower congruence scores (Vlaams Belang). Support for more ideological similarities among rightist parties seems absent. The social democratic party S.pa, the only mass party, does not exhibit the largest nationalization score, but instead hardly surpasses the average score. The traditional parties (Sp.a, CD\&V and Open Vld) adopt intermediate positions, whereas new parties are located at both ends of the scale. At one side, we find the regionalist party $(\mathrm{N}-\mathrm{VA})$ which is most strongly nationalized $(\mathrm{M}=.79)$ and the greens (GROEN) $(\mathrm{M}=.78)$. On the other side, we come across the extreme right party Vlaams Belang that can be characterized as the most weakly nationalized party. 
Figure 2: Relative Nationalization Score per party $(\mathrm{N}=89)$

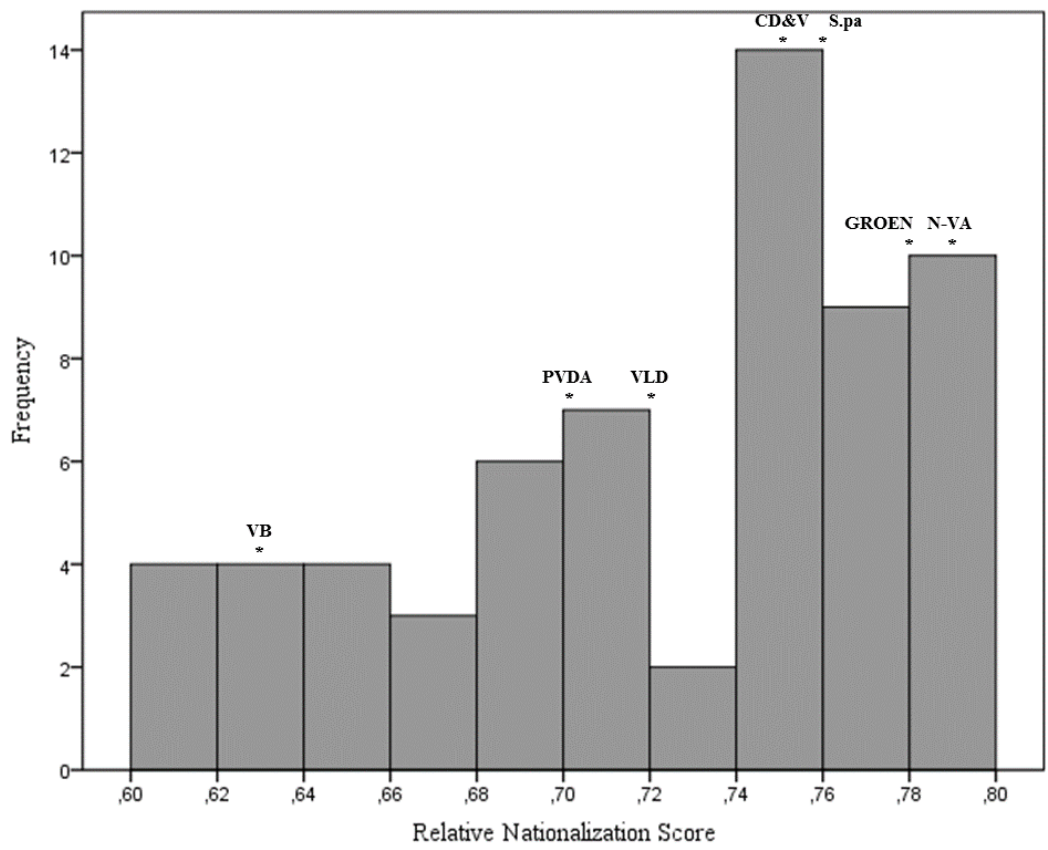

The local context does seem to have a more clear-cut impact on contentual similarities. The manifestos of governing party branches seem to have an average RNS of .76 while the average RNS of 'non-majority' parties was .73 (p<.001). A positive relationship between the Relative Nationalization Score and belonging to the local coalition (Pearson Rho .215, p<.05) confirms the descriptives. It is striking that the results contradict our assumption. We expected an effect of professionalism, i.e. that mayors or aldermen would have an advantage of time and ressources as professional politicians compared to their legislative colleagues. This, however, does not seem to hold. The results indicate an opposite relationship: local party elites with an executive mandate keep tighter relations with the national party than the 'less important' local councillors that are on the opposition bench.

Our data also suggests partial evidence of the positive relation between municipal size and ideological nationalization, meaning that the manifestos of parties in large cities indeed tend to be more congruent with the national model programs. The correlation (Pearson Rho .203), however, barely exceeds the .05 significance boundary $(\mathrm{p}=.057)$. We assume that the small sample size is mainly responsible for this low significance level. One could even interpret this municipal autonomy as national indifference for the performance of rural communities because the 
most important battle is fought in larger cities. Moreover, national leaders or top party officials are disproportionally located in cities and could very well advocate the partyline in their local department. Nevertheless, these results seem to indicate a positive relation between municipal size and the degree of nationalization, providing some preliminary proof of hypothesis $3 \mathrm{~b}$.

\section{The multivariate analysis}

Before introducing all previous indicators into a multivariate regression analysis, we discuss the correlation matrix of our dependent variable, the amount of ideological resemblance, and the six independent variables (see appendix, table b). All correlations, however, with our Relative Nationalization Score are rather disappointing. Only the ideological position of a party has an influence on the level of congruence. Rightwing parties have significantly lower nationalization scores (rejecting H2a). The social democratic mass party, on the other hand, behaves the way we expect it to (confirming $\mathrm{H} 2 \mathrm{~b}$ ). Traditional parties leave limited breathing room for their local departments as it is shows a positive correlation (confirming H2c). Readers should, however, be warry to generalize these effects as significance levels flirt with the conservative thresholds.

Table 2 reveals our three hierarchical regression models. The first model focusses on the influence of party characteristics and demonstrates that, contradictory to our theoretical presumptions, that the threefold party categorization does not have any predictive power. The bivariate results are simply confirmed. The coefficients show no significant effects when only accounting for parties. It is not surprising then, that the $\mathrm{R}^{2}$ is negligible and the model itself is not significant as well.

The second model does explain some of the variation in ideological nationalization. Controlling for party type, residing in the local majority increases the Relative Nationalization Score with 0.044. This leads us to reject our hypothesis $\mathrm{H} 3$ as the relationship is positive. Professionalism could in this regard lead to the intertwining of political elites and, therefore, more discipline. The introduction of this first context variable furthermore has a two folded effect, because coefficients for the right wing parties also increased. The effect in the multivariate model now ressembles the effect in the bivariate correlation matrix more closely. The ideological position of a party on the left-right scale has an effect, albeit small, on the nationalization degree. Caution is advised when interpreting the coefficients, as we deal with a small sample size and the levels of significant are set accordingly.

The third model adds the municipal size as an explanatory variable and increases the viability of our predictive effors. Local departments in large cities show increasing similarities with the national level, which supports the first of our two contrasting hypotheses (H3b). In addition, the results of the last model are in line 
with earlier studies on party system nationalization and their conclusion that municipal size indeed matters. The third model is the only one that significantly succeeds in explaining some variation in ideological nationalization. However, only $14 \%$ of the variation can be attributed to our theoretical explications. The three subhypotheses concerning the effect of party types should all be rejected. The ideological position does contribute to the model, only the direction of the effect is reversed. Exactly the same could be said for taking part in the local coalition. Executive leaders within the municipality branch increases central-local congruence.

Table 2: Multivariate Linear Regression of Ideological Nationalization (RNS) at the Flemish Local Elections of 2012

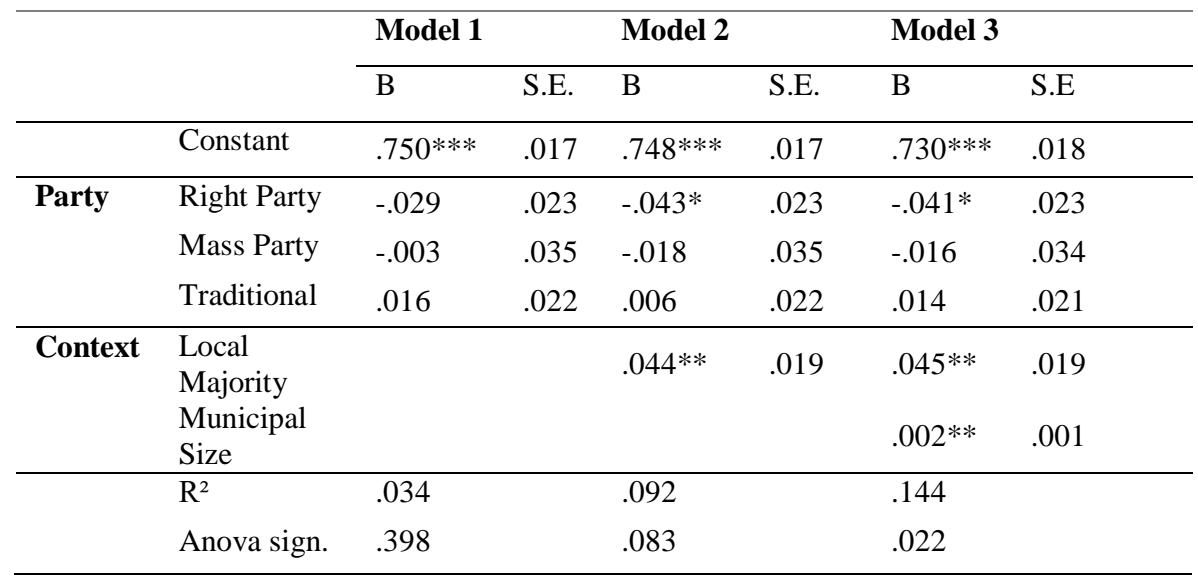

Note: $* \mathrm{p}<.1 ; * * \mathrm{p}<.05 ; * * * \mathrm{p}<.01$

\section{Conclusions}

This article has tried to assess the extent of ideological nationalization of local elections by measuring the congruence between the election manifestos of local chapters and the model programs provided by the central headquarters of national political parties. We demonstrated that the overall degree of ideological nationalization at the local level (measured as the congruence in relative attention for specific categories) is relatively high for all Flemish parties. Thus, birds of a feather do flock together and their sound might be best described as rather unisono. This remarkable result enriches the pending debate on the nationalization of local politics with empirical support, which is usually confined to party supply and electoral success. In contrast to the latter, and especially compared to contemporary studies on nationalization in Belgium, we found clear-cut signs of central-local similarities. 
It also adds to the underdevelopped research domain of political parties at the local level by empirically assessing the relation between the national headquarter and its local branches trough the perspective of ideological nationalization. We propose two major explanations for the ideological uniformity revealed here. On the one hand, the high degree of nationalization could be attributed to the success of the party headquarters and, therefore, support the main assumptions of Carty's franchise party model (2004). According to this model, programmatic issues are mostly a matter of the central party to ensure " $[\ldots]$ that the party is providing a consistent message to its supporters and the electorate". Our analysis indeed illustrates that the national party brand is imposed through the model program that serves as a guiding mechanism or a blueprint for departments. We would argue that these local chapters only tinker minimaly with this template depending on the local needs, but do not deviate heavily from the national manifesto's core. On the other hand, local branches are often weakly organized and regarded as electoral machines. Participating during the elections, froming a party list and campaigning are their main focal points, whereas developping a manifesto is time- and resource-consuming. The programmatic agreement, therefore, could be interpreted alternatively as a pragmatic constraint for local chapters instead of national dominance.

The ideological impact of the national party headquarter on its local chapters is thus very substantial in our sample. Still, variation exists and we have probed into different party and context factors to potentially account for this diversity trough multivariate analysis. Overall, the explanatory power of our models is weak. Generally, the local context performs better as an indicator of local-national similarity than the party factors. More specifically, only right wing parties are significantly less ideologically nationalized, whereas mass and traditional parties did not significantly influence the RNS. Conversely, party chapters included in the departing local majority and those active in larger municipalities show a significantly higher ideological nationalization. The limited amount of explained variance in the multivariate model, however, leaves ample room for additional explanations. For instance, individual factors might play a vital role, such as the presence of a local politician in the party in central office, the capacity (in terms of time, personal or policy expertise) to write a manifesto with truely municipal accents, the ideological ressemblance between the president of a local party chapter and the overall party line, etcetera.

The results also show that local autonomy, and in this case the freedom of party branches, is rather limited, even when considering the ideological dimension. Although this might be preferrable from the perspective of the national party, the restricted leeway could impede the focus on local problems. To illustrate, local policy-makers might be driven to certain choices to soothe the national party and not the local voter, because they are aware that the headquarters watches closely whether the local note matches the national message. The national party strategy 
then becomes more important than the concerns of the local voter. Although party branch autonomy might be constricted, a thematic overlap does not necessarily entail an identical position. Departements could opt to emphasize other, often place-bound, concerns within the central theme proposed by the party. Nevertheless, the results seem to support the franchise party model and suggest that headquarters are succesful in coordinating and steering local departments towards the national template. Despite the potential drawback for the municipal branch, ideological similarities could assist local voters. Hence, the national party label and the associated key issues can function as a shortcut for voters to pick out the party that corresponds best with their own ideological viewpoints. However, it should be noted that ideological resemblances should not be exaggerated. Political parties will probably develop the overall campaign strategy and impose the party line including some key issues, but it is plausible that local departments propose distinct accents within these themes. Moreover, other aspects of nationalization did not point to a straightforward national dominance (see literature review) and could easily counterbalance the national demands during the campaign.

This paper is one of the first to study the ideological dimension of nationalization from a local perspective and through a quantitative content analysis. The design, however, has some unavoidable limitations and exposes some clear avenues for further research. Our cross-sectional approach, for example, is unable to asses whether local-central relations have evolved over time. A longitudinal study, therefore, should examine if localities have gained or lost autonomy. The article, on the other hand, has proven that local election manifestos are fruitful political documents to study, even though they have not attracted abundant scholarly attention untill now. Our method took the first step by focussing on the congruence between party levels in terms of the relative attention dedicated to designated policy domains but should be complemented by considering position as well. Furthermore, analyzing local manifestos could help unravel other interesting questions in local politics. For instance, combining content analysis and local manifestoes could, as a next step in this line of reseach, be a fruitful way of testing the role of ideology in coalition theories. Furthermore, manifesto data could help identify problems concerning local acountability. Are local parties aware of their campaign promises when they enter the municipal executive board, and to what extent do they actually realise them? In short, we hope to have triggered interest for ideology and manifesto research at the local level. 


\section{References:}

Aars, J., \& Ringkjob, H. E. (2005) Party politicization reversed? Non-partisan alternatives in Norwegian local politics, Scandinavian Political Studies, 28(2), pp. 161-182.

Ackaert, J. (2006) Politiek in mijn gemeente (Leuven: Uitgeverij Davidsfonds).

Agasoster, B. (2001) A framework for analysing local party policy emphases in Scotland, In: M. Laver (ed.) Estimating the policy positions of political actors (London: Routledge), pp. 76-89.

Ashworth, R. (2000) Party manifestoes and local accountability: a content analysis of local election pledges in Wales, Local Government Studies, 26(3), pp. 11-30.

Bäck, H. (2003) Party politics and the common good in Swedish local government, Scandinavian Political Studies, 26(2), pp. 93-123.

Budge, I. (1987) The internal analysis of election programmes, In: Budge, I., Robertson, D. \& Hearl, D. (eds.) Ideology, strategy and party change: spatial analyses of post-war election programmes in 19 democracies (Cambridge: Cambridge University Press), pp. $15-38$.

Buelens, J., Dumont, P., Rihoux, B. \& Heyndels, B. (2008) Het standpunt van de partij. Wat is belangrijk voor de lokale afdelingen, In: Buelens, J., Rihoux, B. \& Deschouwer, K. (eds.) Tussen kiezer en hoofdkwartier. De lokale partijafdelingen en de gemeenteraadsverkiezingen van 2006 (Brussel: VUBPress), pp. 31-46.

Caramani, D. (2004) The nationalization of politics: the formation of national electorates and party systems in Western Europe (Cambridge: Cambridge University Press).

Carty, R. K. (2004) Parties as Franchise Systems: The Stratarchical Organizational Imperative, Party Politics, 10(1), pp. 5-24, https://doi.org/10.1177/1354068804039118

Copus, C., Wingfield, M., Steyvers, K. \& Reynaert, H. (2012) A Place to Party? Parties and Nonpartisanship in Local Government, In Clarke, S., John, P. \& Mossberger, K. (eds.) The Oxford Handbook of Urban Politics (Oxford: Oxford University Press), pp. 210230.

De Lange, S. (2007) A New Winning Formula? The Programmatic Appeal of the Radical Right. Party Politics, 13(1), pp. 411-435.

Denters, B. (2011) Local Governance, In: Bevir, M. (ed.) The SAGE Handbook of Governance (London: Sage), pp. 252-270.

Deschouwer, K. (1996) Nationale partijen en gemeenteraadsverkiezingen, In: Buelens, J. \& Deschouwer, K. (eds.) De dorpstraat is de wetstraat niet (Brussel: VUBPress), pp. 1325.

Deschouwer, K. (2003) Political Parties in Multi-Layered Systems. European Urban and Regional Studies, 10(3), pp. 213-226.

Deschouwer, K., \& Rihoux, B. (2008) De lokale partijafdelingen. Van hiërarchie naar stratarchie, In: Buelens, J., Rihoux, B. \& Deschouwer, K. (eds.) Tussen kiezer en hoofdkwartier. De lokale partijafdelingen en de gemeenteraadsverkiezingen van 2006 (Brussel: VUBPress), pp. 19-30.

Devos, C., Verlet, D. \& Reynaert, H. (2007) Spreken lokale afdelingen van Vlaamse partijen uit één mond? Res Publica, 49(1), pp. 89-110.

Ennser, L. \& Hansen, M. (2013) The contingent nature of local party system nationalisation: the case of Austria 1985-2009, Local Government Studies, 39(6), pp. 777-791.

Enyedi, Z. \& Linek, L. (2008) Searching for the right organization. Ideology and party structure in East-central Europe, Party Politics, 14(4), pp. 455-477.

Frendreis, J. P., Gibson, J. L., \& Vertz, L. L. (1990) The electoral relevance of local party 
N. Van de Voorde, N. Bouteca, T. Schamp \& K. Steyvers: Birds of a Feather or by Note? Ideological Nationalization of Local Electoral Manifestos in Belgium

organizations, The American Political Science Review, 84(1), pp. 225-235.

Gemenis, K., \& Dinas, E. (2010) Confrontation still? Examining parties' policy positions in Greece, Comparative European Politics, 8(2), pp. 179-201.

Goldsmith, M., \& Page, E. C. (2010) Conclusions, In: Goldsmith, M. \& Page, E. C. (eds.) Changing Government Relations in Europe (Abingdon: Routledge), pp. 247-260.

Gunther, R. \& Diamond, L. (2003) Species of Political Parties: A New Typology, Party Politics, 9(2), pp. 167-199.

Hajnal, Z. \& Trounstine, J. (2014) What Underlies Urban Politics? Race, Class, Ideology, Partisanship, and the Urban Vote, Urban Affairs Review, 50(1), pp. 63-99.

Heidar, K., Kosiara-Pedersen, K. \& Saglie, J. (2012) Party Change and Party Member Participation in Denmark and Norway, In: Blom-Hansen, J., Green-Pedersen, C. \& Skaanning, S.-E. (eds.) Democracy, Elections and Political Parties (Aarhus: Politica), pp. $155-163$.

Janda, K., Harmel, R., Edens, C. \& Goff, G. (1995) Changes in party identity. Evidence from party manifestos, Party Politics, 1(2), pp. 171-196.

Kjaer, U. \& Elklit, J. (2010) Local party system nationalisation: Does municipal size matter? Local Government Studies, 36(3), pp. 425-444.

Kjaer, U. \& Steyvers, K. (2014) Second thoughts on second-order: towards a second-tier model of local elections and voting, 8th General Conference of the European Consortium for Political Research, 2 Sept 2014 - 6 Sep 2014, Glasgow, UK.

Kjellberg, F. (1995) The Changing Values of Local Government, Annals of the American Academy of Political and Social Science, 540(1), pp. 40-50.

Lago, I., \& Montero, J. (2014) Defining and Measuring Party System Nationalization, European Political Science Review, 6(2), pp. 191-211.

LeDuc, L. (2001) Democratizing party leadership selection, Party Politics, 7(3), pp. 323341.

Mair, P. (1999) New Political parties in Long-Established Party Systems: How Successful Are They?, In Beukel, E. K. , Mouritzen, K. K. \& Odense, P. E. (eds.) Elites, Parties and Democracy: Festschrift for Professor Mogens N. Pedersen (Odense: Odense University Press), pp. 207-224.

Marien, S., Dassonneville, R. \& Hooghe, M. (2015) How Second Order Are Local Elections? Voting Motives and Party Preferences in Belgian Municipal Elections, Local Government Studies, 41(6), 898-916, https://doi.org/10.1080/03003930.2015.1048230.

Meguid, B. (2005) Competition Between Unequals: The Role of Mainstream Party Strategy in Niche Party Succes, American Political Science Review, 99(3), pp. 347-359.

Morgenstern, S., \& Swindle, S. (2005) Are Politics Local? An Analysis of Voting Patterns in 23 Democracies, Comparative Political Studies, 38(2), pp. 143-170.

Mustillo, T. \& Mustillo, S. (2012) Party Nationalization in a Multilevel context. Where is the Variance?, Electoral Studies, 31(2), pp. 422-433.

Olislagers, E. \& Steyvers, K. (2014) Choosing Coalition Partners in Belgian Local Government, Local Government Studies, 41(2), pp. 202-219.

Pedahzur, A. \& Brichta, A. (2000) The attractiveness of the seemingly unattractive: an Israeli case. Local Government Studies, 26(3), pp. 55-70.

Pellikaan, H., Van der Meer, T., \& De Lange, S. (2003) The Road From a Depoliticized to a Centrifugal Democracy, Acta Politica, 38(1), pp. 23-49.

Petrocik, J. R. (1996) Issue ownership in presidential elections, with a 1980 case study, American Journal of Political Science, 40(3), pp. 825-850.

Pilet, J.-B., \& Cross, W. P. (2014) The Selection of Political Party Leaders in Contemporary Parliamentary Democracies (Abingdon: Routledge). 
Reiser, M. (2008) Conclusion: independent local lists in Eastern and Western European countries, In: Reiser, M. \& Holtmann, E. (eds.) Farewell to the Party Model? Independent local lists in Eastern and Western European countries (Wiesbaden: VS Verlag), pp. 277-294.

Rokkan, S. (1966) Electoral Mobilization, Party Competition and National Integration, In: Weiner, J. (ed.) Political Parties and Political Development (Princeton: Princeton University Press), pp. 241-265.

Saiz, M. \& Geser, H. (1999) Local Parties in Political and Organizational Perspective (Boulder: Westview Press).

Sharpe, L. (1970) Theories and Values of Local Government, Political Studies, 18(2), pp. $153-174$.

Steyvers, K. \& De Ceuninck, K. (2013) De kracht van verandering of plus ça change? De gemeenteraadsverkiezingen van 2012 in het licht van de trends sinds de fusies van 1976, In: Reynaert, H. \& Steyvers, K. (eds.) De kracht van verankering? De gemeenteraadsverkiezingen van 14 oktober 2012 (Brugge: Vanden Broele), pp. 15-40.

Steyvers, K., Reynaert, H., De Ceuninck, K. \& Valcke, T. (2008) All politics is local, partisan or national? Local lists in Belgium, In: Reiser, M. \& Holtmann, E. (eds.) Farewell to the Party Model? Independent local lists in Eastern and Western European countries (Wiesbaden: VS Verlag), pp. 169-194.

Swianiewicz, P. (1996) The policy preferences and ideologies of candidates in the 1994 Polish local elections, International Journal of Urban and Regional Research, 20(4), pp. 733-743.

Swianiewicz, P. (2014) An Empirical Typology of Local Government Systems in Eastern Europe, Local Government Studies, 40(2), pp. 292-311.

Thorlakson, L. (2006) Party systems in multi-level context, In: Hough, D. \& Jeffery, C. (eds.) Devolution and electoral politics (Manchester: Manchester University Press), pp. $37-52$.

van Haute, E., Amjahad, A., Borriello, A., Close, C. \& Sandri, G. (2012) Party members in a pillarised partitocracy. An empirical overview of party membership figures and profiles in Belgium, Acta Politica, 48(3), pp. 1-24. https://doi.org/10.1057/ap.2012.25.

Volkens, A. (2002) Manifesto conding instructions (Berlin: Wissenschaftszentrum Berlin für Sozialforschung $\mathrm{gGmbH}$ ).

Wauters, B. (2014) Democratising Party Leadership Selection in Belgium: Motivations and Decision Makers, Political Studies, 61(1), pp. 61-80, https://doi.org/10.1111/14679248.12002.

Wayenberg, E., De Rynck, F., Steyvers, K. \& Pilet, J.-B. (2011) Sub-national Democracy in Belgium: A Tale of Regional Divergence?, In: Loughlin, J., Hendriks, F. \& Lidström, A. (eds.) The Oxford Handbook of Local and Regional Democracy in Europe (Oxford: Oxford University Press), pp. 71-95, https://doi.org/10.1017/CBO9781107415324.004.

Wille, F. \& Deschouwer, K. (2007) Het beschermde dorp: nationale tendensen bij gemeenteraadsverkiezingen, Res Publica, 49(1), pp. 67-68. 
N. Van de Voorde, N. Bouteca, T. Schamp \& K. Steyvers: Birds of a Feather or by Note? Ideological Nationalization of Local Electoral Manifestos in Belgium

\section{Appendix}

Appendix a: Locally oriented coding scheme

\begin{tabular}{|c|c|c|}
\hline & Category & Content \\
\hline 1 & $\begin{array}{l}\text { Communication and the } \\
\text { digital revolution }\end{array}$ & $\begin{array}{l}\text { Local communication, e-government, City } \\
\text { marketing, Local campaigns and sensibilization, ICT } \\
\text { and Wi-Fi, Smartphone apps, Reduction of the } \\
\text { administrative burden }\end{array}$ \\
\hline 2 & Culture and tourism & $\begin{array}{l}\text { General spare time policy, Libraries, Nightlife, } \\
\text { Events and concerts, Local societies, Art, Care of } \\
\text { monuments, Festivals, Carnival, Museums }\end{array}$ \\
\hline 3 & Service provision & $\begin{array}{l}\text { Administration, Human resources, Box-office, } \\
\text { Permissions, Opening hours }\end{array}$ \\
\hline 4 & Diversity and integration & $\begin{array}{l}\text { Racism policy, Equality, Accessibility, Sexual } \\
\text { preference policy, Policy towards foreigners, Civic } \\
\text { integration, Freedom of religion }\end{array}$ \\
\hline 5 & Finances & \begin{tabular}{|cccc}
$\begin{array}{c}\text { Budget, Taxes, Administrative rules towards } \\
\text { budgetary control }\end{array}$ & & \\
\end{tabular} \\
\hline 6 & Community & $\begin{array}{l}\text { Flemish culture and identity, Community building, } \\
\text { Social cohesion, Folklore, Neighborhood policy }\end{array}$ \\
\hline 7 & Democratic participation & $\begin{array}{l}\text { Civic Democracy, Consultation, Neighborhood } \\
\text { councils, Advisory boards }\end{array}$ \\
\hline 8 & Family and child care & $\begin{array}{l}\text { Day care, Family policy, Playgrounds, Parental } \\
\text { education, Combination of child and family, Youth } \\
\text { associations }\end{array}$ \\
\hline 9 & Local economy & $\begin{array}{l}\text { Self-employment, Local enterprises, Employment, } \\
\text { Hotel and catering, Industry }\end{array}$ \\
\hline 10 & Environment & $\begin{array}{l}\text { Parks, Energy, Waste, Sewers, Animal care, } \\
\text { Agriculture, Countryside development, Horticulture, } \\
\text { Flooding areas, Water policy }\end{array}$ \\
\hline 11 & Education & $\begin{array}{l}\text { General provision of education, Universities, } \\
\text { Internships, Local art schools, Evening education }\end{array}$ \\
\hline 12 & Elderly care & $\begin{array}{l}\text { Housing designed for seniors, Service apartments, } \\
\text { Retiring homes }\end{array}$ \\
\hline 3 & Political management & $\begin{array}{l}\text { Local government, Policy preparation, cooperation } \\
\text { and coordination, Management function, Executive } \\
\text { board, Inter-municipal cooperation, Local council }\end{array}$ \\
\hline 4 & Environmental planning & $\begin{array}{l}\text { Public maintenance, Public areas, City or town } \\
\text { planning, Infrastructure, Public domain }\end{array}$ \\
\hline 5 & Social policy & $\begin{array}{l}\text { Local social policy, Social welfare, Health policy, } \\
\text { Volunteers, Social housing, Informal care, Personal } \\
\text { debt mediation, Service vouchers, Social activation }\end{array}$ \\
\hline 6 & Sports & Sports areas, Stadium, Swimming pools \\
\hline 7 & Safety & $\begin{array}{l}\text { Police, Fire corps, Criminality, Supervision and } \\
\text { penalization of fraud, Drugs, Local sanctions (GAS, } \\
\text { BIN) }\end{array}$ \\
\hline
\end{tabular}


LEX LOCALIS - JOURNAL OF LOCAL SELF-GOVERNMENT

N. Van de Voorde, N. Bouteca, T. Schamp \& K. Steyvers: Birds of a Feather or by Note? Ideological Nationalization of Local Electoral Manifestos in Belgium

\begin{tabular}{|l|l|l|}
8 & Traffic and mobility & $\begin{array}{l}\text { Road safety, Parking zones, Public transport, } \\
\text { Cyclists and pedestrians, Traffic jams }\end{array}$ \\
\hline 9 & Housing policy & $\begin{array}{l}\text { Housing policy, Housing fraud, Community land } \\
\text { trust, Private property }\end{array}$ \\
\hline
\end{tabular}

Appendix b: Correlation Matrix of Ideological Nationalization (RNS) and six Independent Variables

\begin{tabular}{llllll}
\hline & 1 & 2 & 3 & 4 & 5 \\
\hline RNS & $-.178^{*}$ & .128 & .024 & .172 & .108 \\
1. Right Party & & $-.514^{* * *}$ & .144 & $.207 *$ & -.067 \\
2. Mass Party & & & $.448^{* * *}$ & $.199^{*}$ & -.092 \\
3. Traditional Party & & & & $.387 * * *$ & $-.226 * *$ \\
4. Local Majority & & & & & -.105 \\
5. Municipal Size & & & & & - \\
\hline
\end{tabular}

Note: All correlations are Spearman Rho coefficients.

$* \mathrm{p}<.1 ; * * \mathrm{p}<.05 ; * * * \mathrm{p}<.01$ 